\title{
A review of self-poisoning admissions in a five-bed intensive care unit in scotland
}

\author{
G Warnock*, L Young \\ From ESICM LIVES 2015 \\ Berlin, Germany. 3-7 October 2015
}

\section{Introduction}

Deliberate self-poisoning is a common presentation to hospitals, with 13,268 presentations to Scottish hospitals in 2004 accounting for $1.11 \%$ of total admissions [1]. It accounts for up to $4 \%$ of ICU admissions, with the majority being under forty years old and predominantly male [2]. In a recent study of 481 patients, the average length of stay was 0.7 days, and hospital mortality was $4 \%(\mathrm{n}=20)[2]$.

\section{Objectives}

To assess the epidemiology and outcomes of self-poisoning admissions to our local intensive care unit, and to quantify which substances are currently most prevalent.

\section{Methods}

A WardWatcher ${ }^{\mathrm{TM}}$ search was performed retrospectively for all admissions with the primary unit diagnosis equal to 'self-poisoning'. The search returned 330 records (approximately $4.8 \%$ of all admissions). We excluded any records that were alcohol poisoning only, had no record of what substances were taken, or were missing APACHE data $(\mathrm{n}=156)$.

\section{Results}

A total of 174 records were included in the analysis. The mean age was 37 , and there was a slight propensity for male gender ( $F: M=1: 1.15)$. The mean length of stay was 1.8 days, with $39 \%(n=68)$ staying less than one day. The mean APACHE mortality prediction was $15.3 \%$. Actual unit mortality was $2.3 \%(\mathrm{n}=4)$, with a standardised mortality ratio (SMR) of 0.15 . The most common presentation was that of a mixed overdose in $46.6 \%(n=81)$; the commonest substances taken included anti-depressants in $42.5 \%(\mathrm{n}=74)$, paracetamol-containing drugs in $14.9 \%$

Victoria Infirmary/ NHS Greater Glasgow \& Clyde, Intensive Care Department, Glasgow, United Kingdom

(c) 2015 Warnock et al.; This is an Open Access article distributed under the terms of the Creative Commons Attribution License (http:// creativecommons.org/licenses/by/4.0), which permits unrestricted use, distribution, and reproduction in any medium, provided the original work is properly cited.
( $\mathrm{n}=26)$, and benzodiazepines in $21.3 \%(\mathrm{n}=37)$. Alcohol was also involved as part of the mixed overdose in $25.2 \%$ $(\mathrm{n}=44)$.

\section{Conclusions}

Our review shows a similar demographic for self-poisoning admissions - patients were under forty and there was a slight propensity for male gender. The actual mortality in our dataset was lower than that reported elsewhere, and significantly the SMR was less than one. The most prevalent substance taken in our review was anti-depressants.

Published: 1 October 2015

References

1. Cook R, Allcock R, Johnston M: Self-poisoning: current trends and practice in a UK teaching hospital. Clin Med 2008, 8(1):37-40.

2. Clark D, Murray DB, Ray DC: Epidemiology and outcomes of patients admitted to critical care after self-poisoning. JICS 2011, 12(4):268-272.

doi:10.1186/2197-425X-3-S1-A497

Cite this article as: Warnock and Young: A review of self-poisoning admissions in a five-bed intensive care unit in scotland. Intensive Care Medicine Experimental 2015 3(Suppl 1):A497.

Submit your manuscript to a SpringerOpen ${ }^{\odot}$ journal and benefit from:

- Convenient online submission

- Rigorous peer review

- Immediate publication on acceptance

- Open access: articles freely available online

- High visibility within the field

Retaining the copyright to your article

Submit your next manuscript at $>$ springeropen.com 